\title{
WYBRANE UWARUNKOWANIA KSZTALTUJĄCE SKLONNOŚĆ PRZEDSIĘBIORSTW DO STOSOWANIA NARZĘDZI RACHUNKOWOŚCI ZARZĄDCZEJ W KOLEJNYCH ETAPACH ICH ROZWOJU
}

Wielu badaczy i praktyków gospodarczych podkreśla rolę informacji w procesach zarządzania. Identyfikacja, gromadzenie i przetwarzanie danych jest domeną systemów rachunkowości. Sam system rachunkowości, dysponując określonymi narzędziami (m.in. rachunkiem kosztów), może generować informacje, które znacząco wspomagają zarządzanie, jednak często dane te są niedostateczne do podjęcia celnych, trafnych decyzji. Dlatego pojawił się olbrzymi obszar instrumentów controllingu i rachunkowości zarządczej, uzupełniających tradycyjne rachunki kosztów, a jednocześnie bazujących na danych pochodzących z systemu księgowego. Rola nowoczesnych rachunków kosztów i rachunków ekonomicznych we współczesnych przedsiębiorstwach jest nie do przecenienia. Jednakże nie wszystkie podmioty wykazują jednakowe zainteresowanie implementacja dodatkowych narzędzi analizy i badania efektywności działania. Niewątpliwie wdrożenie całościowego (zintegrowanego) systemu wspomagającego zarządzanie jest powszechne wśród dużych przedsiębiorstw. Rozwiązania w nich przyjmowane to najprostsze rachunki ekonomiczne lub te bardzo rozbudowane, często wykorzystujące statystykę, badania operacyjne czy rachunek prawdopodobieństwa. Wśród mniejszych podmiotów gospodarczych rzadziej spotyka się wielomodułowe systemy wspierające zarządzanie. Jednak zaczynając od podstawowego rachunku ekonomicznego, w kolejnych fazach dojrzałośc i przy wystąpieniu określonych uwarunkowań wśród średnich przedsiębiorstw można zaobserwować zainteresowanie bardziej zaawansowanymi instrumentami analizy.

Celem artykułu jest prezentacja wybranych czynników wpływających na architekturę systemów wspomagających zarządzanie (zwłaszcza uwzględniających narzędzia rachunkowości zarządczej), a także przesłanek kształtujących decyzje o wdrożeniu takich narzędzi. W literaturze obszernie opisywane są procesy wzrastania przedsiębiorstwa, warto mieć jednak na uwadze, że przełomy i kryzysy w życiu podmiotu gospodarczego, stają się często bodźcem albo źródłem inspiracji dla przedsiębiorców podejmujących decyzje o implementacji specyficznych instrumentów z zakresu zarządzania bądź rachunkowości zarządczej i controllingu.

Słowa kluczowe: rachunkowość zarządcza, controlling, systemy wspierające zarządzanie

\section{WPROWADZENIE}

Potrzeba zastosowania innowacyjnych narzędzi wspomagających procesy decyzyjne w przedsiębiorstwie może wynikać z wielu różnych czynników. Ogólnie czynniki te można podzielić na wewnętrzne i zewnętrzne. Wśród czynników wewnętrznych należy zwrócić uwagę przede wszystkim na rozmiar przedsiębiorstwa, a co za tym idzie - jego potrzeby informacyjne. Kolejnym niewątpliwie będzie rola przedsiębiorcy i właściciela w kształtowaniu przyszłości podmiotu i budowaniu jego strategii. Oczywiście niezwykle ważne będą model i styl

${ }^{1}$ Dr inż. Adriana Kaszuba-Perz, Zakład Finansów i Bankowości, Politechnika Rzeszowska, Rzeszów, Al. Powstańców Warszawy 8, 35-959 Rzeszów, mail: aperz@prz.edu.pl. 
zarządzania, który $\mathrm{w}$ gruncie rzeczy również powiązany jest $\mathrm{z}$ miejscem przedsiębiorcy $\mathrm{w}$ organizacji i jego roli w systemie zarządzania. Warto również wspomnieć o takich czynnikach, które mają nieco inny charakter i bywają powiązane z takimi dziedzinami, jak psychologia czy socjologia, a nawet filozofia prowadzenia „biznesu”. Jednym z nich może być koncepcja przedsiębiorczości organizacyjnej opisywana między innymi przez Mariusza Bartnickiego² ${ }^{2}$

W artykule przedstawiono wybrane czynniki kształtujące wśród przedsiębiorców potrzebę implementacji instrumentów rachunkowości zarządczej w zależności od stopnia dojrzałości i etapu wzrostu podmiotu gospodarczego. W opracowaniu omówiono tylko niektóre uwarunkowania oparte na ciekawych (zdaniem autorki) współczesnych koncepcjach zarządzania. Ze względu na znaczenie dla budowy systemów rachunkowości zarządczej i controllingu w procesie wzrostu małych i średnich przedsiębiorstw wybrano do analizy takie obszary, które uważa się jednocześnie za charakterystyczne dla tej grupy przedsiębiorstw, a więc: przedsiębiorczość, elastyczność, skłonność do ryzyka, czynniki o charakterze behawioralnym (jako że zwłaszcza w małych i średnich przedsiębiorstwach dużą rolę przypisuje się między innymi osobowości przedsiębiorcy), rolę identyfikacji i pomiaru ryzyka (właśnie małym i średnim przedsiębiorstwom przypisuje się bowiem skłonność do podejmowania ryzyka) oraz przedsiębiorczość organizacyjną.

\section{WYBRANE CZYNNIKI WYWODZACE SIE Z KONCEPCJI ZARZADZANIA I ICH ZNACZENIE DLA BUDOWY SYSTEMÓW RACHUNKOWOŚCI ZA- RZĄDCZEJ I CONTROLLINGU W ROZWIJAJĄCYCH SIĘ MALYCH I ŚREDNICH PRZEDSIĘBIORSTWACH}

Złożoność i wielorakość czynników wpływających na architekturę i formę systemów rachunkowości zarządczej i controllingu jest oczywista i wyczerpująco opisywana przez praktyków i teoretyków w tej dziedzinie. Potwierdzają to popularyzowane koncepcje między innymi teoria Freemana ${ }^{3}$ czy rachunkowość behawioralna ${ }^{4}$. Teoria interesariuszy wprawdzie początkowo odnosiła się wyłącznie do zarządzania, jednakże zaczęto ją również stosować w rachunkowości zarządczej. Wielu badaczy podkreśla duże znaczenie uwarunkowań wewnętrznych $\mathrm{w}$ procesach wdrażania zaawansowanych rachunków ekonomicznych, w tym zwłaszcza rolę szeroko rozumianego kapitału ludzkiego. Zaangażowanie, wiedza, doświadczenie i inwencja pracowników i zarządzających komórkami finansowo-księgowymi to czynniki, które znacząco wpływają na kształt systemu informacyjnego rachunkowości i ewentualnie wdrażanych, powiązanych ze sobą modułów wspomagających procesy zarządzania ( $w$ tym również służących badaniu efektywności).

Z punktu widzenia ścieżki rozwoju małego przedsiębiorstwa i przemian w nim zachodzących istotną funkcję będą pełniły badania behawioralne. Oczywiście zwłaszcza w najmniejszych podmiotach niezaprzeczalną rolę odgrywają cechy osobowościowe przedsiębiorcywłaściciela, warto jednak zwrócić uwagę, że wraz z rozwojem struktury organizacyjnej i oddelegowaniem uprawnień decyzyjnych na niższe szczeble podobne znaczenie będą one miały w wypadku pracowników średniego szczebla zarządzania. Jeśli na koncepcję wzrostu organizacji nałoży się mapę zapotrzebowania informacyjnego, okaże się, że nie tylko będzie ono

\footnotetext{
${ }^{2}$ M. Bartnicki, Sprawdzanie teorii przedsiębiorczości, „Przedsiębiorstwo przyszłości” 3/8 (2011).

${ }^{3}$ R.E. Freeman, Strategic Management: A Stakeholder Approach, Pitman, Boston 1984.

${ }^{4}$ Szerzej na ten temat: N. Artienwicz, Rachunkowość behawioralna jako interdyscyplinarny nurt rachunkowości i społecznych nauk o zachowaniu, ,Zeszyty Teoretyczne Rachunkowości” 71/127 (2013), s. 7-23.
} 
rosło - co jest oczywiste, lecz będą zachodziły zmiany funkcji tych informacji. Jedne z ważniejszych badań w tej dziedzinie przeprowadzili Jacob G. Birnberg i Jeffrey F. Shields, klasyfikując główne obszary rachunkowości behawioralnej: kontrolę kierowniczą, przetwarzanie informacji w rachunkowości finansowej, projektowanie informacyjnych systemów rachunkowości, audyt wewnętrzny i zewnętrzny oraz socjologię organizacyjną ${ }^{5}$. Warto podkreślić że ze względu na normatywny, sformalizowany charakter rachunkowości finansowej pierwsze badania nad rachunkowością behawioralną dotyczyły oczywiście rachunkowości zarządczej, dopiero później w dziedzinie ogólnopojętej rachunkowości i socjologii organizacyjnej ${ }^{6}$. Biorąc pod uwagę wybrane narzędzia rachunkowości zarządczej i ich funkcje, które są uwarunkowane czynnikami społecznymi, należy wymienić przede wszystkim planowanie, zwłaszcza przy wykorzystaniu budżetowania, kontrolę oraz generowanie raportów - sprawozdań. Te wymieniane są najczęściej przez badaczy, jednakże istnieje również wiele innych z nimi powiązanych - jak chociażby rachunek odpowiedzialności czy niektóre decyzyjne rachunki kosztów (rachunek kosztów docelowych, rachunek kosztów cyklu życia produktu). Dobór właściwych instrumentów analizy oraz tych wspomagających procesy podejmowania decyzji jest wszakże ściśle powiązany ze stopniem dojrzałości przedsiębiorstwa. Warto jednak zwrócić uwagę, że nawet w grupie małych przedsiębiorstw zdarzają się przedsiębiorcy - innowatorzy skłonni do wdrażania nowinek również w dziedzinie rachunków ekonomicznych. Oczywiście inne będą motywy i czynniki (a przynajmniej siła wybranych spośród nich) implementacji decyzyjnych rachunków kosztów i wyników w wypadku małych, średnich i dużych przedsiębiorstw. Duże znaczenie będzie miało również to, czy przedsiębiorstwo znajduje się $\mathrm{w}$ fazie przemian lub przełomu.

Kolejnym istotnym czynnikiem wpływającym na procesy decyzyjne, a tym samym stosowane instrumentarium, jest ryzyko. Ryzyko jest pojęciem niezwykle szerokim i bardzo często definiowanym. Jednakże na potrzeby niniejszego opracowania w pierwszej kolejności autorka posłuży się definicją prakseologiczną, w której świetle ryzyko „stanowi prawdopodobieństwo zajścia negatywnych zdarzeń niezależnych od podmiotu działającego, których nie może on przewidzieć i którym nie można w pełni zapobiec, a które - przez zmniejszenie wyników użytecznych i/lub przez zwiększenie kosztów - odebrałyby działaniu zupełnie lub częściowo cechę skuteczności, korzystności i ekonomiczności”7 . Ryzyko jest niewątpliwie zjawiskiem stwarzającym szanse biznesowe lub grożącym niepowodzeniem. W encyklopedii organizacji i zarządzania, podkreśla się istotną cechę ryzyka, a mianowicie możliwość jego pomiaru przy wykorzystaniu rachunku prawdopodobieństwa lub metod statystycznych ${ }^{8}$. Problematyka ryzyka i niepewności - takie pojęcia wyróżniają bowiem klasycy tej dziedziny ${ }^{9}$, Frank Knight jednakże precyzuje, że jedynie takie zdarzenia - sytuacje, dla których można obiektywnie określić prawdopodobieństwo, można nazwać ryzykiem, wszystkie pozostałe są zjawiskami

${ }^{5}$ J.G. Birnberg, J.F. Shields, Three decades of behavioral accounting research. A search for order, „Behavioral Research In Accounting” 1989/1, s. 23-74, cyt. za: N. Artienwicz, Rachunkowość behawioralna jako interdyscyplinarny nurt $w$ rachunkowości $i$ społecznych nauk o zachowaniu, „Zeszyty Naukowe Rachunkowości” 71/127 (2013), s. 7-23.

${ }^{6}$ Zob. szerzej: A. Szychta, Etapy ewolucji i kierunki integracji metod rachunkowości zarządczej, Wydawnictwo Uniwersytetu Łódzkiego, Łódź 2008.

${ }^{7}$ T. Pszczołowski, Mała encyklopedia prakseologii i teorii organizacji, Zakład Narodowy im. Ossolińskich, Wrocław 1978, s. 215-216.

${ }^{8}$ Encyklopedia organizacji i zarządzania, PWE, Warszawa 1982, s. 456.

${ }^{9}$ Zob. między innymi J.M. Keynes, A treatise on Probability, London 1921; F. Knight, Risk. Uncertainty and Profit, London 1971, s.19-20. 
niepowtarzalnymi, a wówczas mówi się o niepewności. Do istoty pomiaru ryzyka odnosi się również Edward Nowak, który zwraca uwagę na możliwości zaistnienia określonych wyników lub też ich niewystępowania ${ }^{10}$. Z takiego punktu widzenia ryzyko rozpatrują Maria Sierpińska i Tomasz Jachna, definiując je jako niebezpieczeństwo niezrealizowania założonych celów ${ }^{11}$. Warto również przytoczyć klasyfikację definicji ryzyka według Waldemara Rogowskiego i Jacka Grzywacza - jest ona dość istotna z punktu widzenia tematu niniejszego opracowania. W zależności od położonego nacisku na procesy zachodzące $\mathrm{w}$ organizacji rozróżnili pięć obszarów: decyzyjny, działania, planistyczny, obszar strat, obszar celów ${ }^{12}$. Każde przedsiębiorstwo dąży do optymalizacji rozwiązań przyjmowanych w określonych sytuacjach, do niwelowania bądź ograniczania niebezpieczeństw, które mogłyby zagrozić osiągnięciu celów bądź spowodować negatywne od niego odchylenia. Nie bez znaczenia są również niebezpieczeństwa poniesienia straty, zarówno te wynikające z uwarunkowań wewnętrznych, jak i zewnętrznych. Na podstawie obszernej dyskusji w literaturze ekonomicznej na potrzeby omawianej problematyki można przyjąć, że ryzyko jest zjawiskiem, które po zidentyfikowaniu można zmierzyć (metodami statystycznymi i rachunkiem prawdopodobieństwa), niepewność zaś - jakkolwiek mająca olbrzymie znaczenie w działalności gospodarczej - nie ma cech, które pozwoliłyby na jej pomiar. Pomiar odchyleń od założonych celów jest jedną z ważniejszych funkcji rachunkowości zarządczej. Wśród jej narzędzi występują, tak chętnie stosowane przez różnej wielkości przedsiębiorstwa: budżetowanie i rachunek odpowiedzialności. W wypadku obu tych instrumentów obowiązuje zasada uprzedniości, a zatem identyfikacja ryzyk, już na etapie planowania będzie miała olbrzymie znaczenie. Oczywiście kształt systemu identyfikacji i pomiaru ryzyka jest uwarunkowany wieloma czynnikami, podobnie jak jego miejsce w systemie zarządzania przedsiębiorstwem ${ }^{13}$.

Istotnym czynnikiem kształtującym systemy rachunkowości zarządczej i controllingu w przedsiębiorstwach, jest przedsiębiorczość organizacyjna. Pojęcie samej przedsiębiorczości jest obszernie omawiane w literaturze przedmiotu. Najczęściej jest rozumiana jako postawa, której charakterystyczną cechą jest podejmowanie inicjatyw, dynamizm w działaniu, kreatywność, innowacyjność, a nawet skłonność do podejmowania ryzykownych decyzji i elastyczność w dopasowywaniu się do wymagań rynku ${ }^{14}$. Do tych cech odwołano się już we wstępie niniejszego opracowania. Inną definicję przedsiębiorczości podają również Robert D. Hisrich oraz Michael P. Peters, traktując ją jako proces kreowania czegoś odmiennego, czemu poświęca się czas i wysiłek, akceptując towarzyszące mu finansowe i społeczne ryzyko, a jednocześnie oczekując efektów finansowych i satysfakcji ${ }^{15}$. Warto w tym miejscu przytoczyć również definicję Peter Druckera, który z kolei podkreśla silne związki przedsiębiorczości z otoczeniem, mówiąc o niej jako o wydarzeniu, które może kształtować ekonomię ${ }^{16}$.

\footnotetext{
${ }^{10}$ E. Nowak, Decyzje inwestycyjne w warunkach niepewności i ryzyka, „Serwis Finansowo-Księgowy” 1996/13.

${ }^{11}$ M. Sierpińska, T. Jachna, Ocena przedsiębiorstwa wedtug standardów światowych, PWN, Warszawa 1993, s. 232.

${ }^{12}$ W. Rogowski, J. Grzywacz, Ryzyko kredytowe - pojęcie oraz klasyfikacje, „Bank i Kredyt” 1999/10.

${ }^{13}$ Szerzej na ten temat: A. Kaszuba-Perz, P. Perz, Rola zarzadzania ryzykiem w przedsiębiorstwie w obliczu wzrostu zewnętrznych czynników ryzyka, „eFinanse”, http://www.e-finanse.com/artykuly/144.pdf.

${ }^{14}$ W. Kasperkiewicz, S. Mikosik, Leksykon przedsiębiorczości: pojęcia, osoby, instytucje, Wydawnictwo Uniwersytetu Łódzkiego, Łódź 1993.

${ }^{15}$ R.D. Hisrich, M.P. Peters, Enterpreneurship. Tarting, developing and managing a new enterprise, Irving, Boston 1992, s. 10

${ }^{16}$ P.F. Drucker, Innowacja i przedsiębiorczość. Praktyka i zasady, PWE, Warszawa 1992, s. 30.
} 
Suma cech podanych w przytoczonych definicjach przedsiębiorczości oraz funkcje, jakie przypisuje się przedsiębiorczości organizacyjnej, składają się zatem już na pewną koncepcje systemu ukierunkowanego nie tylko na przetwarzanie danych ex post, lecz również generowanie informacji o charakterze ex ante - a te są przecież trzonem budowania strategii organizacji rozwijającej się. W ślad za tym można stwierdzić, że koncepcja przedsiębiorczości organizacyjnej może, a nawet powinna zostać powiązana z instrumentami, które wprost mogą wspomagać dążenie do osiągnięcia takiego stopnia rozwoju, w którym kultura przedsiębiorczości będzie sama w sobie siłą napędową wzrostu. Niewątpliwie dużą rolę w tym względzie będzie odgrywał kapitał ludzki.

Jak uzasadnia w swojej pracy Marian Mroziewski, olbrzymie znaczenie dla budowania kolejnego etapu przedsiębiorczości organizacyjnej ma pełne wykorzystanie kompetencji organizacji. Organizacje gospodarcze zaś cechujące się takową przedsiębiorczością wykazują się sprawnym dostrzeganiem i wykorzystywaniem szans rynkowych oraz pełniejszym wykorzystaniem wewnętrznego potencjału i zdolności, są również skłonne do podejmowania większego ryzyka ${ }^{17}$. Skłonność do podejmowania ryzyka (jak już wspomniano) jest domeną mniejszych przedsiębiorstw, jednakże w podmiotach o rozbudowanej kulturze przedsiębiorczej cecha ta również będzie obecna. Warto jednak zaznaczyć, że w przedsiębiorstwach dojrzalszych (większych) przedsiębiorca lub zarządzający będą wykazywać większą skłonność do jego mierzenia i porównywania z potencjalnymi korzyściami.

Przedstawione czynniki w świetle wybranych koncepcji zarządzania i cech organizacji przedsiębiorczej przekładają się na kształt systemów controllingu i rachunkowości zarządczej, wspomagających zarządzanie przedsiębiorstwem. Skłonność przedsiębiorców i zarządzających do stosowania takich instrumentów będzie uzależniona nie tylko od tych czynników, ale i od stopnia rozwoju organizacji.

\section{PROCESY WZROSTU MALYCH I ŚREDNICH PRZEDSIĘBIORSTW A AR- CHITEKTURA SYSTEMÓW ZARZĄDZANIA}

Zastosowanie instrumentów analizy zależy nie tylko od modelu zarządzania, wielkości przedsiębiorstwa, jego dojrzałości, kompetencji i zaangażowania menedżerów, lecz również może wynikać z chwilowej potrzeby wywołanej na przykład przełomem strategicznym. Pojęcie przełomu jest definiowane często jako nagła zmiana lub kryzys ${ }^{18}$. Problematyka przemiany, zmiany w procesach rozwojowych przedsiębiorstw jest obszernie omawiana w literaturze przedmiotu. Zjawiska te są często przedstawiane w kontekście wyboru strategicznego ${ }^{19}$. Jednakże warto zwrócić uwagę na podział zmian na takie, które są realizowane w sposób ciągły, systematyczny, oraz takie, które przebiegają skokowo. Konsekwencją tych pierwszych jest ustawiczne doskonalenie organizacji, efektem tych o charakterze skokowym zaś jest radykalna zmiana - a nawet „wdrożenie nowego modelu biznesu” 20 .

\footnotetext{
${ }^{17}$ Zob. szerzej na ten temat: M. Mroziewski, Styl zarzadzania jako instytucjonalny czynnik kreowania kapitału przedsiębiorczości organizacyjnej. Koncepcja ewolucyjno-normatywna, Wydawnictwo Uniwersytetu Gdańskiego, Gdańsk 2010, s. 122-123.

${ }^{18}$ Encyklopedia popularna PWN, wyd. XXX, Wydawnictwo Naukowe PWN, Warszawa 1999, s. 698.

${ }^{19}$ Szerzej na ten temat w: M. Romanowska, Planowanie strategiczne $w$ przedsiębiorstwie, wyd. II zmienione, PWE, Warszawa 2009, s. 16-19; P. Banaszyk, S. Cyfert, Strategiczna odnowa przedsiębiorstwa, Centrum Doradztwa i Informacji Difin, Warszawa 2007.

${ }^{20}$ P. Banaszyk, S. Cyfert, op. cit., s. 11.
} 
Zatem bez względu na wielkość przedsiębiorstwa, a także etap jego rozwoju w momencie kryzysu czy też nagłej zmiany rola instrumentów rachunkowości zarządczej lub ogólnie rachunków ekonomicznych jest nie do przecenienia. Moment taki w życiu przedsiębiorstwa staje się często impulsem do podjęcia decyzji o implementacji tego typu narzędzi i ich systematycznego stosowania. Wpływ omawianych wcześniej obszarów uwarunkowań na system zarządzania przedsiębiorstwem zaprezentowano na rysunku 1 .

Rys. 1 Czynniki wpływające na architekturę systemu wspomagającego zarządzanie w średnich i dużych przedsiębiorstwa.

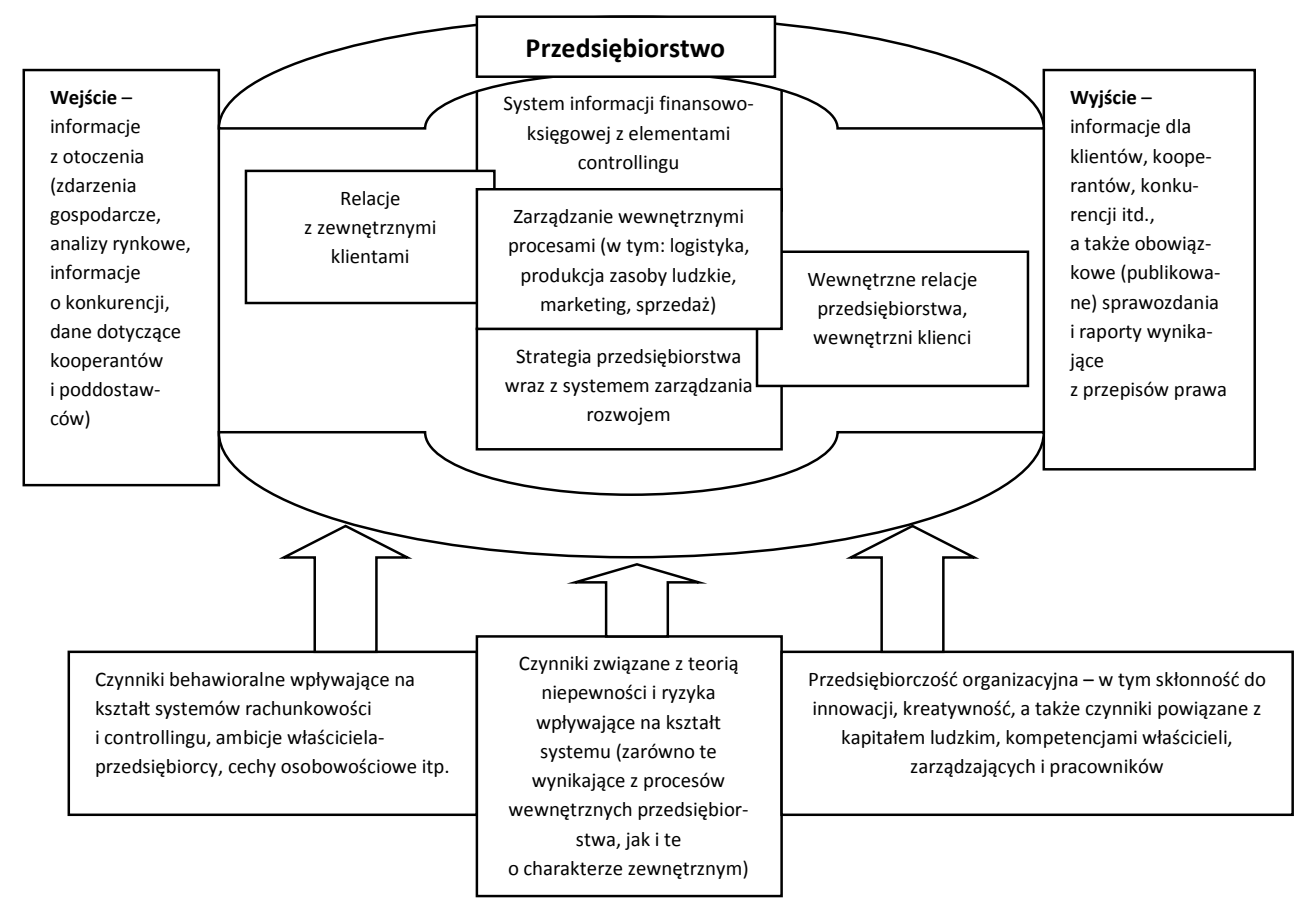

Źródło: opracowanie własne

Warto podkreślić, że większość relacji zaprezentowanych na schemacie ma strukturę sieciową, zagadnienia te są bowiem od siebie zależne i ściśle ze sobą związane. Czy zatem współczesne narzędzia rachunkowości zarządczej i controllingu dają możliwość uwzględnienia tych obszarów (w tym także takich, które wydają się niemierzalne)? Odpowiedzią są coraz nowsze rozwiązania $\mathrm{w}$ zakresie zintegrowanego zarządzania $\mathrm{z}$ uwzględnieniem narzędzi controllingowych, dostosowane do potrzeb konkretnych firm. Jednakże takie rozwiązania są najczęściej możliwe jedynie w przypadku dużych przedsiębiorstw. Te mniejsze, dopiero rozwijające się mogą jedynie korzystać $\mathrm{z}$ rozwiązań popularnych, powszechnych, co również w niektórych wypadkach będzie stanowiło spore wyzwanie. Poszczególne grupy czynników, a w zasadzie ich siła oddziaływania na decyzje o wdrożeniu, rozbudowie lub przebudowie systemu controllingowego, będą różne - zależne od etapu wzrostu przedsiębiorstwa oraz sytuacji, w której aktualnie podmiot się znajduje. W okresach wczesnego rozwoju duże znaczenie będą miały czynniki o charakterze behawioralnym oraz te związane ze zjawiskiem niepewno- 
ści. W podmiotach dojrzalszych natomiast większe znaczenie będzie się przypisywać czynnikom powiązanym z przedsiębiorczością organizacyjną, kompetencjami, kapitałem ludzkim. Warto pamiętać, że w okresach przełomu dużą rolę mogą odgrywać czynniki zewnętrzne (polityczno-gospodarcze, środowiskowe, informacje o konkurencji itd.).

\section{PODSUMOWANIE}

Na tle ogólnej teorii wzrostu przedsiębiorstwa ważną rolę należy przypisać systemom informacyjnym, które wspomagają zarządzanie. W kolejnych etapach rozwoju małego przedsiębiorstwa, z inicjatywy samego przedsiębiorcy bądź też w wyniku przełomów lub też kryzysów, menedżerowie czy też właściciele w mniejszym lub większym stopniu usiłują stosować choćby elementarne narzędzia analizy i rachunku ekonomicznego. Zważywszy na współczesne koncepcje zarządzania, podjęto próbę powiązania tychże z ogólną ideą zintegrowanego zarządzania przedsiębiorstwem przy znaczącym udziale instrumentów rachunkowości zarządczej oraz controllingu. Mimo interdyscyplinarnego charakteru dzisiejszych, często nowatorskich modeli zarządzania, które uwzględniają zgoła niemierzalne dziedziny, takie jak kapitał ludzki, przedsiębiorczość, behawioralne podejście do nauk ekonomicznych, badanie niepewności i ryzyka, okazuje się bowiem, że w dbałości o przyszłość organizacji (w tym małych przedsiębiorstw) nieodzowne są jednak pewne formy ich pomiaru (wykorzystujące między innymi statystykę, rachunek prawdopodobieństwa, badania operacyjne i inne). Skoro więc zagadnienia te pełnią funkcję czynników wpływających na sposób zarządzania i tym samym kształt systemów wspomagających, to zarządzanie wobec tego staje się jednocześnie ważnym elementem systemów controllingowych. Metody pomiaru tychże czynników zaś stanowią i stanowić będą wciąż podstawę do dalszych badań.

\section{LITERATURA}

[1] Artienwicz N., Rachunkowość behawioralna jako interdyscyplinarny nurt rachunkowości i społecznych nauk o zachowaniu, „Zeszyty Teoretyczne Rachunkowości” 71/127 (2013).

[2] Banaszyk P., Cyfert S., Strategiczna odnowa przedsiębiorstwa, Centrum Doradztwa i Informacji Difin, Warszawa 2007.

[3] Bartnicki M., Sprawdzanie teorii przedsiębiorczości, „Przedsiębiorstwo przyszłości” 3/8 (2011).

[4] Controlling funkcyjny w przedsiębiorstwie, red. M. Sierpińska, Oficyna Wydawnicza, Kraków 2004.

[5] Drucker P.F., Innowacja i przedsiębiorczość. Praktyka i zasady, PWE, Warszawa 1992.

[6] Encyklopedia organizacji i zarządzania, PWE, Warszawa 1982.

[7] Encyklopedia popularna PWN, wyd. XXX, Wydawnictwo Naukowe PWN, Warszawa 1999.

[8] Freeman R.E., Strategic Management: A Stakeholder Approach, Pitman, Boston 1984.

[9] Garg A., Gosh D., Hudic J., Nowacki Ch., Roles and Practices In Management Accounting Today: Results from the 2003 IMA -E\&Y Survey, „Strategic Finance” 2003, cyt. za: B. Szkudlarek, E. Zarzycka, Możliwości zastosowania niemieckich rozwiąań praktycznych systemów rachunku kosztów w przedsiębiorstwach z innych krajów, [w:] Rachunkowość, audyt i kontrola $w$ zarządzaniu, red. I. Sobańska i M. Turzyński, Wydawnictwo Uniwersytetu Łódzkiego, Łódź 2011.

[10] Hisrich R.D., Peters M.P., Enterpreneurship. Tarting, developing and managing a new enterprise, Irving, Boston 1992, s. 10.

[11] Kasperkiewicz W., Mikosik S., Leksykon przedsiębiorczości: pojęcia, osoby, instytucje, Wydawnictwo Uniwersytetu Łódzkiego, Łódź 1993. 
[12] Kaszuba-Perz A., Perz P., Rola zarządzania ryzykiem w przedsiębiorstwie w obliczu wzrostu zewnętrznych czynników ryzyka, „eFinanse”, http://www.e-finanse.com/artykuly/144.pdf.

[13] Keynes J.M., A treatise on Probability, London 1921.

[14] Klonowski Z.J., Systemy Informatyczne Zarzadzania Przedsiębiorstwem. Modele rozwoju i właściwości funkcjonalne, Oficyna Wydawnicza Politechniki Wrocławskiej, Wrocław 2004.

[15] Knight F., Risk. Uncertainty and Profit, London 1971.

[16] Mroziewski M., Styl zarządzania jako instytucjonalny czynnik kreowania kapitalu przedsiębiorczości organizacyjnej. Koncepcja ewolucyjno-normatywna, Wydawnictwo Uniwersytetu Gdańskiego, Gdańsk 2010.

[17] Nowak E., Decyzje inwestycyjne w warunkach niepewności i ryzyka, „Serwis FinansowoKsięgowy" 1996/13.

[18] Pszczołowski T., Mała encyklopedia prakseologii i teorii organizacji, Zakład Narodowy im. Ossolińskich, Wrocław 1978,

[19] Rogowski W., Grzywacz J., Ryzyko kredytowe - pojęcie oraz klasyfikacje, „Bank i Kredyt” 1999/10.

[20] Romanowska M., Planowanie strategiczne w przedsiębiorstwie, wyd. II zmienione, PWE, Warszawa 2009.

[21] Sierpińska M., Jachna T., Ocena przedsiębiorstwa wedtug standardów światowych, PWN, Warszawa 1993.

[22] Skrzypek E., Jakość i efektywność, Wyd. UMCS, Lublin 2000.

[23] Systemy informacyjno-decyzyjne zarzadzania, red. A. Nowicki, Wydawnictwo Akademii Ekonomicznej im. Oskara Langego we Wrocławiu, Wrocław 1991.

[24] Szychta A., Etapy ewolucji i kierunki integracji metod rachunkowości zarządczej, Wydawnictwo Uniwersytetu Łódzkiego, Łódź 2008.

[25] Zarzadzanie wiedza informacja $w$ procesie doskonalenia jakości, red. E. Skrzypek, Wydawnictwo UMCS, Lublin 2001.

\section{SELECTED FACTORS INFLUENCING THE PROPENSITY OF COM- PANIES TO APPLY MANAGEMENT ACCOUNTING TOOLS IN THE NEXT STAGES OF THEIR DEVELOPMENT}

Many researchers and business practitioners emphasize the role of information in management process. Identification, data collection and processing is the domain of accounting systems. Accounting system has specific tools which can generate information, which significantly support the management but often this information is insufficient for making good decisions. For this reason, there's a huge area of controlling and management accounting instruments, which support traditional cost accounting. These instruments are based on data from the accounting system. The role of modern cost accounting in contemporary enterprises couldn't be underestimated. However, not all organizations show an interest in the implementation of additional tools for efficiency analysis. Undoubtedly, the implementation of a holistic (integrated) business management software (like ERP systems) is common among large organizations. Such software used solutions based on simplest cost accounting or very sophisticated based on statistic, operational research or probability theory. Among the smaller enterprises, complicated business management systems are less commonly used. However, during evolution of the companies from small to bigger ones, if there is occurrence of certain conditions, interest in more advanced instruments for analysis can be observed.

The aim of the paper is to present some factors that influence the architecture of ERP systems (especially taking into account the management accounting tools). Also, the conditions which influence the decisions about the implementation of such tools are discussed. Although the processes of growth of the enterprises are widely discussed in the eco- 
nomic literature, it is worth to consider that crises in the organization may be incentive or a source of inspiration for entrepreneurs for making decisions about the implementation of specific management, management accounting or controlling instruments.

Keywords: managerial accounting, controlling, ERP systems

DOI: 10.7862/rz.2014.mmr.18

Tekst złożono w redakcji: kwiecień 2014

Przyjęto do druku: czerwiec 2014 